\title{
Intracranial Pressure Responses During Hyperbaric Oxygen Therapy
}

\author{
Kiyotaka KOHSHI***, Akira YOKOTA**, Nobuhide KONDA*, \\ Yoshimasa KINOSHITA** and Hidehiko KAJIWARA** \\ Departments of ${ }^{*}$ Hyperbaric Medicine and ${ }^{* *}$ Neurosurgery, University of \\ Occupational and Environmental Health, Kitakyushu, Fukuoka
}

\begin{abstract}
The responses of intracranial pressure (ICP) to hyperbaric oxygen ( $\mathrm{HBO}$ ) therapy and arterial gas pressures were investigated. ICP was measured through a ventricular or spinal drainage catheter in patients with brain tumor or cerebrovascular disease. Changes in ICP, heart rate (HR), arterial blood pressure (ABP), and transcutaneous partial pressure of carbon dioxide $\left(\mathrm{PtcCO}_{2}\right)$ or oxygen $\left(\mathrm{PtCO}_{2}\right)$ were recorded continuously during air or $100 \% \mathrm{O}_{2}$ breathing at 1 and 2.5 atmospheres absolute (ATA). HR and $\mathrm{PtcCO}_{2}$ decreased and mean ABP was unchanged during $\mathrm{HBO}$ inhalation. ICP was reduced at the beginning and tended to increase gradually during $\mathrm{HBO}$ inhalation. The change from air to $\mathrm{O}_{2}$ without altering respiratory frequency and volume caused a gradual increase of ICP and $\mathrm{PtcCO}_{2}$ with a transient ICP reduction in an artificially respirated patient. Intentionally reduced respiration to maintain $\mathrm{PtcCO}_{2}$ at the value at $2.5 \mathrm{ATA}$ with air caused the ICP to return to near the value at 2.5 ATA with air even during $\mathrm{HBO}$ inhalation. These findings suggest that reduced ICP is initially due to direct cerebral vasoconstriction caused by hyperoxia and is maintained mainly by induced hypocapnia during HBO inhalation. Care is required when giving HBO therapy to patients with a high ICP and/or who are respirated artificially.
\end{abstract}

Key words: blood gases, carbon dioxide, hyperbaric oxygen, intracranial pressure

\section{Introduction}

Cerebral vasoconstrictive effects of hyperbaric oxygen (HBO) have been demonstrated in both clinical and experimental investigations. ${ }^{6,9,10,12,14-16,21)}$ HBOinduced reduction of cerebral blood flow (CBF) and increased intracranial pressure (ICP) is beneficial in various neurological conditions when brain edema is present. ${ }^{11,18-20)}$ ICP reduction during HBO inhalation is apparently caused by vasoconstriction, but whether the effect is directly due to $\mathrm{HBO}$ or to hypocapnia secondary to $\mathrm{HBO}$ is unknown. We, therefore, continuously recorded partial pressure of both oxygen $\left(\mathrm{PO}_{2}\right)$ and carbon dioxide $\left(\mathrm{PCO}_{2}\right)$ using transcutaneous devices during 50-minute HBO therapy to investigate the effects of arterial gases on ICP.

\footnotetext{
Received August 20, 1990; Accepted January 11, 1991
}

\section{Materials and Methods}

The ICP and transcutaneous $\mathrm{PO}_{2}\left(\mathrm{PtcO}_{2}\right)$ and $\mathrm{PCO}_{2}$ $\left(\mathrm{PtcCO}_{2}\right)$ were investigated in 11 patients with postoperative acute brain damage. Two patients presented with brain tumor, five subarachnoid hemorrhage, one cerebral hemorrhage, one ruptured arteriovenous malformation, and two cerebellar hemorrhage. The patients received external ventricular or spinal drainage and HBO therapy for postoperative neurological impairment (Table 1).

HBO therapy was performed in a multiplace hyperbaric chamber (P-1000SA, Hanyuda, Tokyo). The therapy schedule was 15-minute compression with air, 10-minute air breathing, 50-minute $100 \%$ $\mathrm{O}_{2}$ inhalation using an $\mathrm{O}_{2}$ mask at 2.5 atmospheres absolute (ATA), 10-minute decompression with $\mathrm{O}_{2}$ inhalation.

The parameters monitored were $\mathrm{PtcO}_{2}, \mathrm{PtcCO}_{2}$, heart rate $(\mathrm{HR})$, respiratory pattern and rate (RR). $\mathrm{PtcO}_{2}$ was monitored by a TCMl TC oxygen monitor (Radiometer, Copenhagen, Denmark). 
Table 1 Clinical summary of the neurosurgical patients treated with $\mathrm{HBO}$

\begin{tabular}{|c|c|c|c|c|c|c|}
\hline $\begin{array}{l}\text { Case } \\
\text { No. }\end{array}$ & Age & $\begin{array}{l}\text { Interval from } \\
\text { operation to } \\
\text { HBO therapy } \\
\text { (days) }\end{array}$ & Diagnosis & $\begin{array}{l}\text { Neurological } \\
\text { status at } \\
\text { HBO therapy }\end{array}$ & Respiration & $\begin{array}{l}\text { Mean ICP at } \\
1 \text { ATA with air } \\
\text { (mmHg) }\end{array}$ \\
\hline 1 & 59 & 6 & $\begin{array}{l}\text { cerebellar } \\
\text { hemorrhage }\end{array}$ & semicoma & $\begin{array}{l}\text { spontaneous } \\
\text { intubated }\end{array}$ & 8.5 \\
\hline 2 & 31 & 13 & $\begin{array}{l}\text { cerebellar } \\
\text { hemorrhage }\end{array}$ & ataxia & spontaneous & 9.6 \\
\hline 3 & 59 & 6 & $\begin{array}{l}\text { cerebral } \\
\text { hemorrhage }\end{array}$ & coma & $\begin{array}{l}\text { artificial } \\
\text { (barbiturate } \\
\text { therapy) }\end{array}$ & 10.5 \\
\hline 4 & 53 & 10 & brain tumor & ataxia & spontaneous & 10.9 \\
\hline 5 & 16 & 8 & brain tumor & hemiparesis & spontaneous & 7.6 \\
\hline 6 & 61 & 14 & ruptured AVM & confusion & spontaneous & 16.3 \\
\hline 7 & 67 & 7 & $\begin{array}{l}\text { subarachnoid } \\
\text { hemorrhage }\end{array}$ & hemiparesis & spontaneous & 9.7 \\
\hline 8 & 48 & 5 & $\begin{array}{l}\text { subarachnoid } \\
\text { hemorrhage }\end{array}$ & semicoma & spontaneous & 11.4 \\
\hline 9 & 49 & 12 & $\begin{array}{l}\text { subarachnoid } \\
\text { hemorrhage }\end{array}$ & somnolence & spontaneous & 9.1 \\
\hline 10 & 58 & 11 & $\begin{array}{l}\text { subarachnoid } \\
\text { hemorrhage }\end{array}$ & somnolence & spontaneous & 6.4 \\
\hline 11 & 31 & 8 & $\begin{array}{c}\text { subarachnoid } \\
\text { hemorrhage }\end{array}$ & confusion & spontaneous & 10.2 \\
\hline
\end{tabular}

ATA: atmosphere absolute, AVM: arteriovenous malformation, HBO: hyperbaric oxygen, ICP: intracranial pressure.

The $\mathrm{PtcO}_{2}$ sensor was calibrated with ambient air. $\mathrm{PtcCO}_{2}$ was monitored by a Model 634 (Kontron Medical, Zürich, Switzerland). The $\mathrm{PtcCO}_{2}$ sensor was stable and accurate during compression to 41 bar and decompression in rats, ${ }^{4}$ and calibrated with two gas mixtures $\left(5 \%\right.$ and $10 \% \mathrm{CO}_{2}: \mathrm{N}_{2}$ for balance, Calibrator 344, Kontron Instruments, Ltd., Zürich, Switzerland). Arterial blood pressure (ABP) was monitored using calibrated strain-gauge P-50 transducers (Statham, U.S.A.) through an arterial catheter. The HR was determined from the electrocardiogram. The $\mathrm{PtcCO}_{2}$ and $\mathrm{HR}$ were expressed as mean \pm SD for each patient every 5 minutes. The respiratory pattern was monitored by the impedance method and the RR averaged every 30 seconds.

The ICP was measured through the ventricular or spinal drainage catheter with the patient in the supine position using calibrated strain-gauge transducers referenced to the external auditory meatus. The baseline ICP was measured 1 hour or more before compression, to eliminate any ICP increase due to obliteration of the external cerebrospinal fluid drainage system. All parameters including the maximum and minimum ICP values were recorded continuously by a programmable data logger (7VO7, NEC San-Ei Sokki, Tokyo) every 10 seconds before, during, and after HBO therapy (about 2 hours).

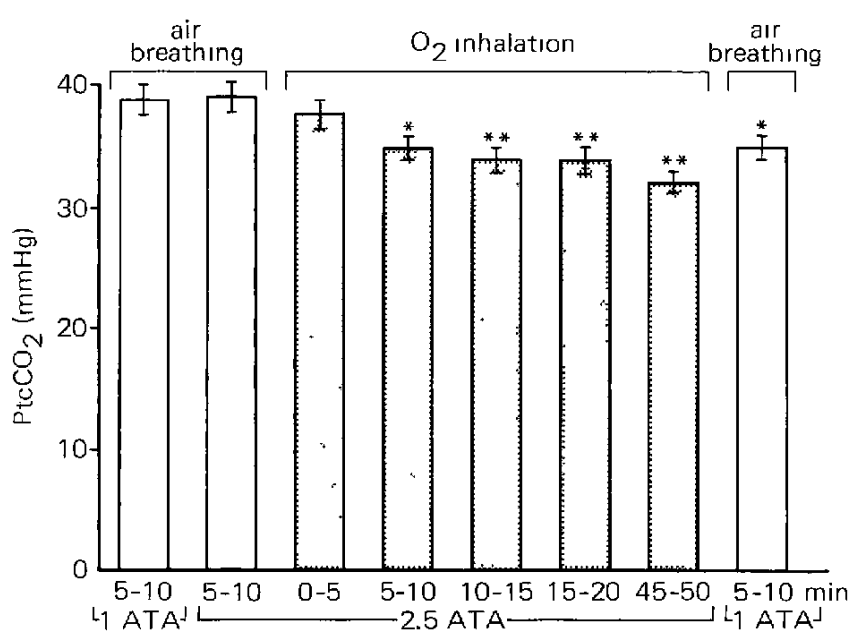

Fig. 1 Changes in mean $\mathrm{PtcCO}_{2}$ during $\mathrm{HBO}$ therapy in all spontaneously respirated patients $(n=10)$. $\mathrm{PtcCO}_{2}$ decreased gradually during $100 \% \mathrm{O}_{2}$ inhalation at 2.5 ATA. The first significant difference is observed 5-10 minutes after $\mathrm{O}_{2}$ inhalation. The subsequent $\mathrm{PtcCO}_{2}$ values with $100 \% \mathrm{O}_{2}$ inhalation are significantly lower than those at $2.5 \mathrm{ATA}$ with air. The lowest value is seen just before the start of decompression (4550 minutes after $\mathrm{O}_{2}$ inhalation). $\mathrm{PtcCO}_{2}$ is raised gradually after decompression. ${ }^{*} \mathrm{p}<$ 0.05 and ${ }^{* *}$ p $<0.01$ vs. 2.5 ATA with air. 
The small number of patients and various illnesses prevents statistical analysis for the case studies. The $t$ test was used to compare common variables such as $\mathrm{HR}$ or $\mathrm{PtcCO}_{2}$ data. Data were obtained every $10 \mathrm{sec}-$ onds and averaged over 5 minutes (30 points) or 1 minute (6 points) in each subject. The mean and SD were then calculated. The two variables were correlated by least square linear regression for each subject. Any statistical significance was then evaluated.

\section{Results}

The most consistent changes during HBO therapy were a decrease in $\mathrm{PtcCO}_{2}$ and $\mathrm{HR}$. The mean $\mathrm{PtcCO}_{2}$ did not change at 2.5 ATA with air, but decreased gradually during $\mathrm{HBO}$ inhalation (Fig. 1). However, continuous measurements showed the $\mathrm{PtcCO}_{2}$ rose transiently at the beginning of $\mathrm{HBO}$ inhalation and then decreased gradually during HBO inhalation. The RR did not change, but the respiratory depth increased and hyperventilation continued during HBO inhalation. During decompression after $\mathrm{HBO}$ inhalation, the RR reduced transiently and the $\mathrm{PtcCO}_{2}$ increased to the previous level (Fig. 2). The HR decreased significantly by compression to 2.5 ATA $(\mathrm{p}<0.01)$, and the reduction continued during HBO inhalation $(p<0.05$ compared to HR at 2.5 ATA with air).

Experiment 1 (Fig. 3): The 10 spontaneous breathing patients usually demonstrated rapidly decreased ICP at the beginning of HBO inhalation which tended to increase gradually during $\mathrm{HBO}$ inhalation. The $\mathrm{PtcCO}_{2}$, however, decreased gradually during $\mathrm{HBO}$ inhalation. The ICP and $\mathrm{PtcCO}_{2}$ increased during and after decompression. ICP also decreased rapidly with $\mathrm{O}_{2}$ inhalation at 1 ATA.

Experiment 2 (Fig. 4): In the patient undergoing barbiturate therapy (Case 3 ), respiration was artificially controlled at 2.5 ATA with air to maintain the same $\mathrm{PtcCO}_{2}$ as at 1 ATA. When $\mathrm{O}_{2}$ at 2.5 ATA was supplied without any change in respiratory frequency or volume, the ICP and $\mathrm{PtcCO}_{2}$ increased

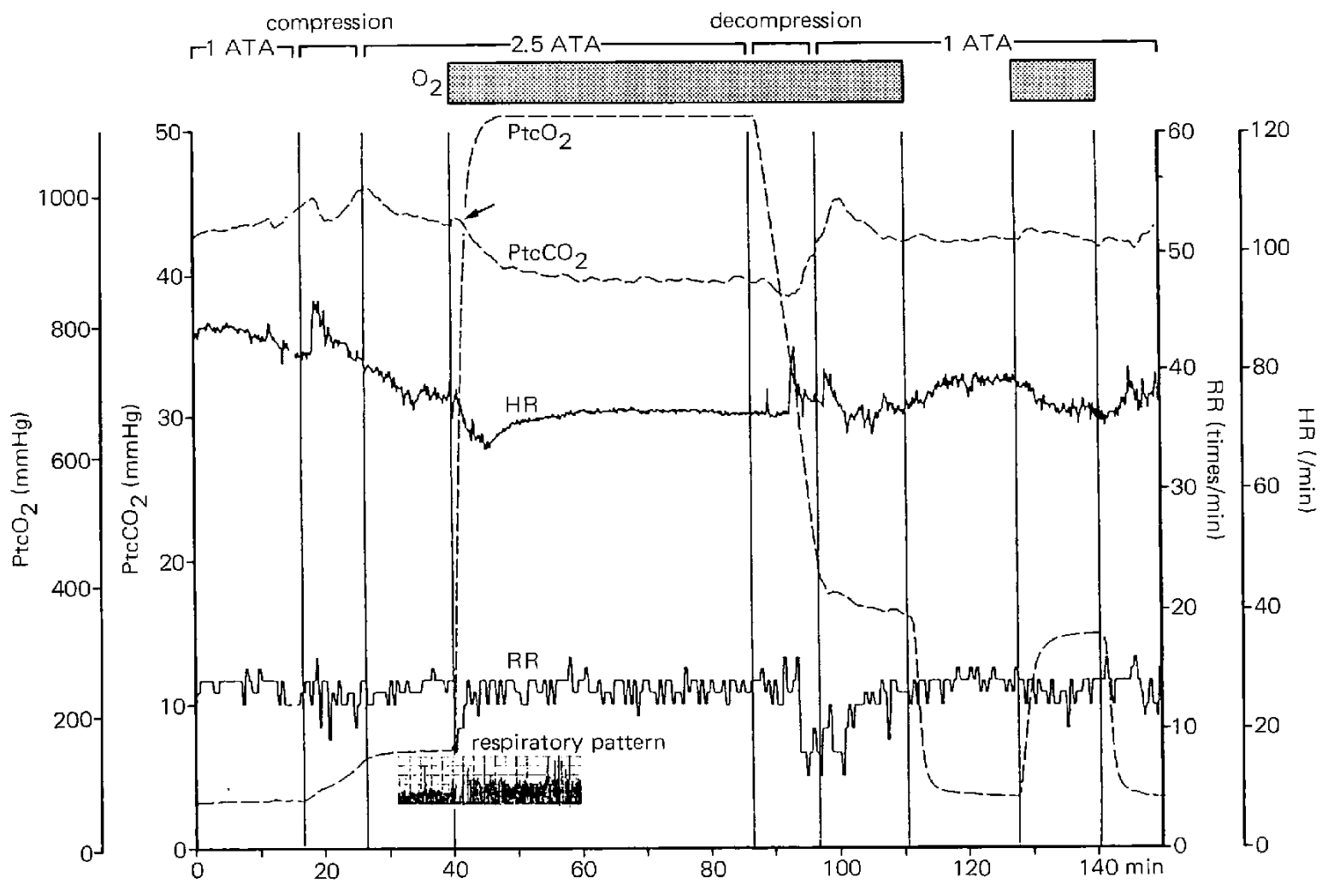

Fig. 2 Changes in blood gases and heart (HR) and respiratory rates ( $R \mathrm{R})$ during $\mathrm{HBO}$ therapy in Case 1 . $\mathrm{HR}$ is reduced by both compression and $\mathrm{O}_{2}$ inhalation, and the reduction continued during $\mathrm{HBO}$ inhalation. $\mathrm{RR}$ is not changed by $\mathrm{HBO}$ inhalation, but respiratory depth increased. $\mathrm{PtcCO}_{2}$ rises slightly in the first 2-5 minutes (arrow) and then decreases gradually during HBO inhalation. RR decreases during decompression. 


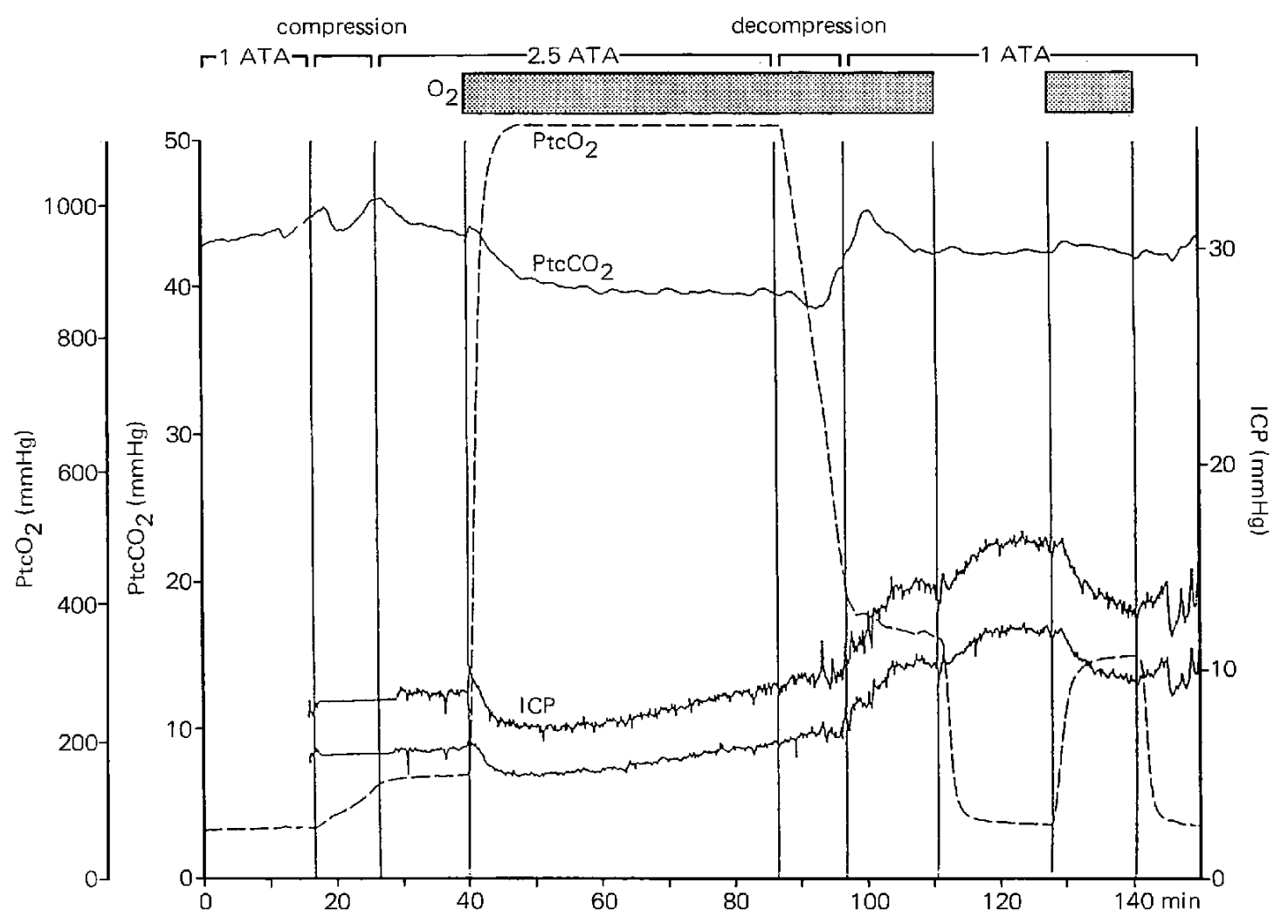

Fig. 3 Changes in ICP and blood gases during HBO therapy in Case 1. ICP decreases rapidly with the start of $\mathrm{O}_{2}$ inhalation at both 1 and $2.5 \mathrm{ATA}$, and rises gradually during HBO. The ICP increase is marked after HBO.

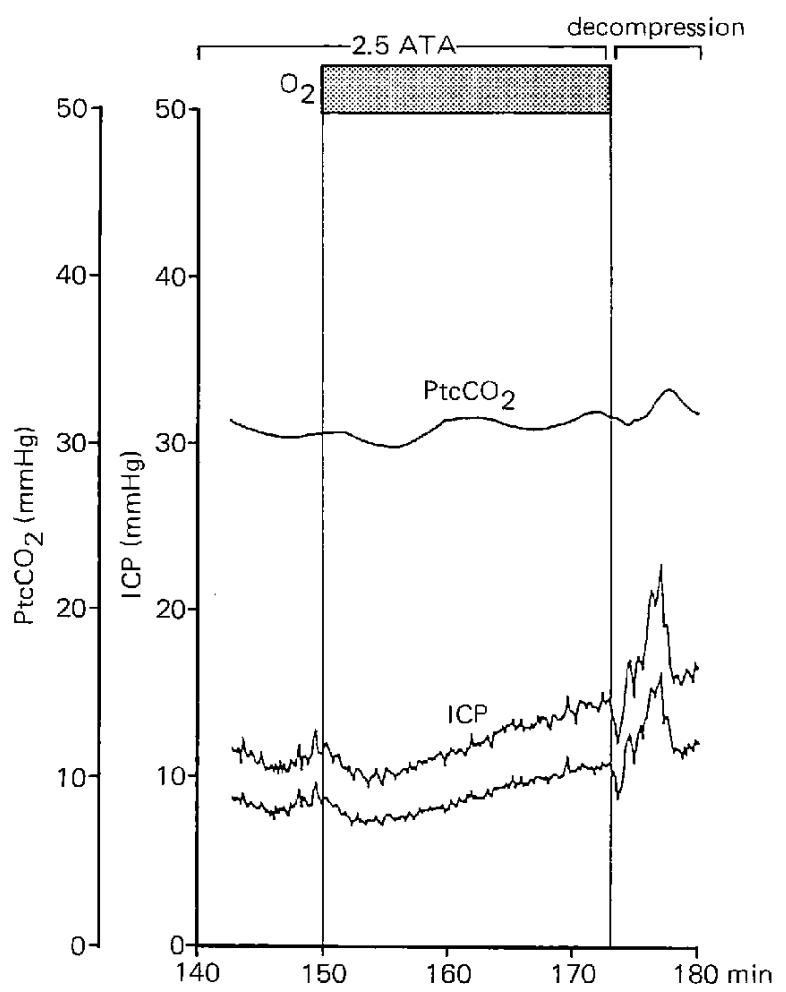

gradually with a transient ICP reduction.

Experiment 3 (Figs. 5 and 6): A cooperative patient (Case 4) was asked to reduce respiration to maintain the same $\mathrm{PtcCO}_{2}$ as at $2.5 \mathrm{ATA}$ with air. The decreased ICP increased gradually toward the value at 2.5 ATA with air in spite of HBO inhalation. When the intentional reduction in respiration was discontinued, both $\mathrm{PtCCO}_{2}$ and $\mathrm{ICP}$ rapidly decreased again.

Two patients demonstrated no initial ICP response to $\mathrm{HBO}$ inhalation. One (Case 7) showed only a slight $\mathrm{PtcCO}_{2}$ decrease when intentional hyperventilation was requested during both 1 ATA with air and $\mathrm{HBO}$ inhalation. In the other patient (Case 2, $\mathrm{PtcCO}_{2}$ and ICP started to decrease about 5 minutes after $\mathrm{HBO}$ inhalation began, but no initial

Fig. 4 ICP changes during HBO therapy in Case 3, a comatose patient requiring artificial respiration. When air is changed to $\mathrm{O}_{2}$ at 2.5 ATA without altering respiratory frequency and volume, both ICP and $\mathrm{PtcCO}_{2}$ increase gradually with a transient ICP reduction. 


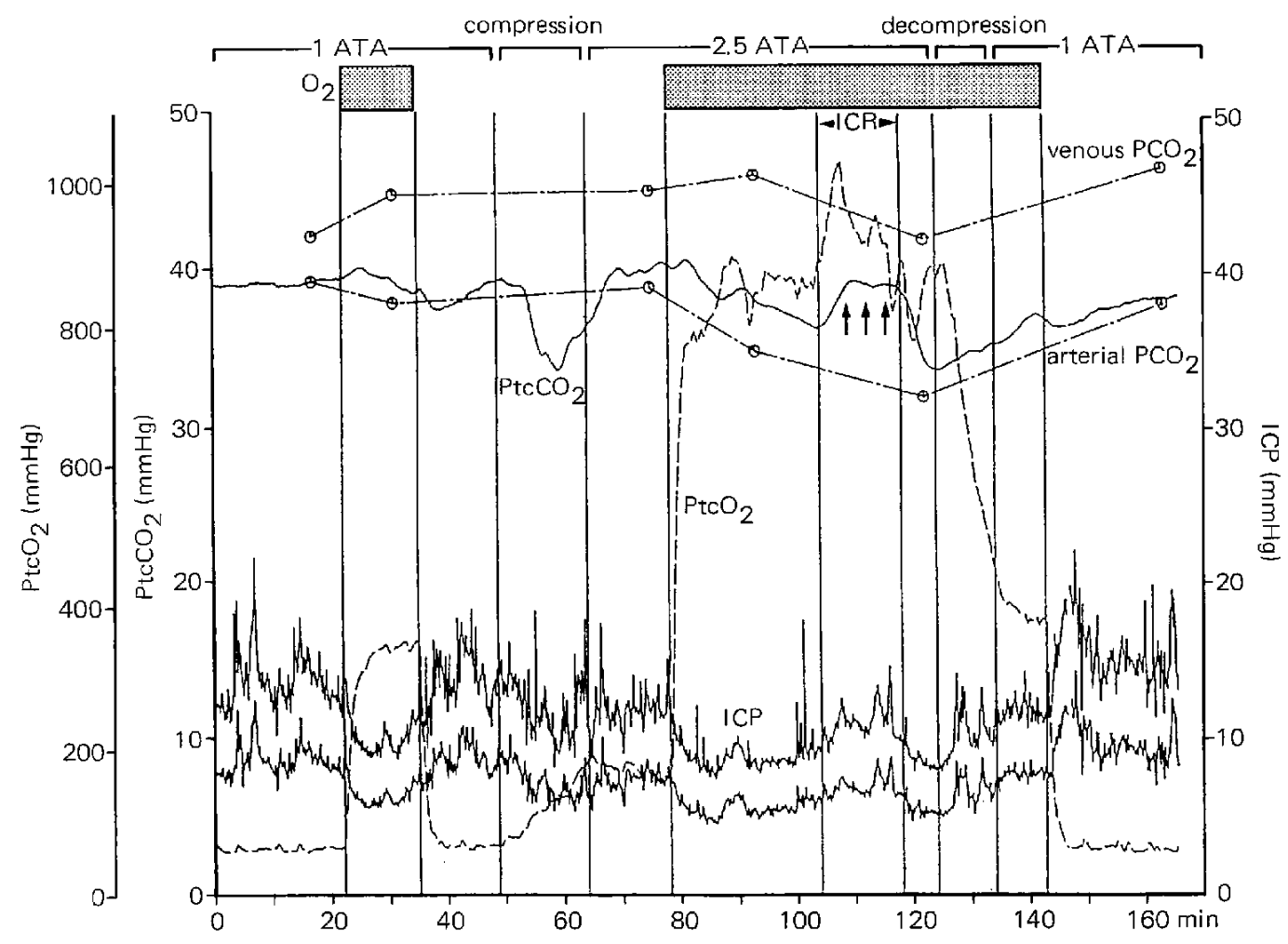

Fig. 5 ICP changes during HBO therapy and changes in blood gases with intentionally controlled respiration in Case 4. ICP returns to the value at 2.5 ATA with air when $\mathrm{PtCCO}_{2}$ is maintained at the value at 2.5 ATA with air (arrows). ICR: intentionally controlled respiration.

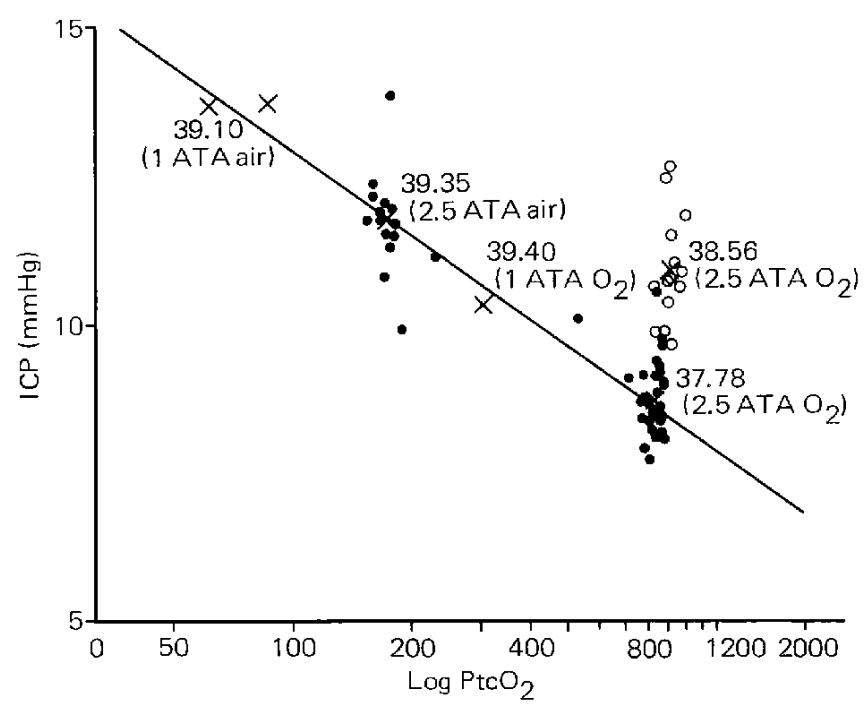

Fig. 6 The correlation between ICP and the logarithm of $\mathrm{PtcO}_{2}$ in Case 4. ICP during intentionally induced normocapnia $(O)$ is significantly higher than that in the $\mathrm{HBO}$ induced hypocapnia (๑). Values in the figure denote $\mathrm{PtcCO}_{2}(\mathrm{mmHg})$ in each condition.
ICP reduction was seen.

\section{Discussion}

Dautrebande and Haldane ${ }^{3)}$ first suggested that HBO has a direct cerebral vasoconstrictive effect. Animal experiments have also demonstrated that the $\mathrm{CBF}$ and/or ICP decrease during $\mathrm{HBO}$ inhalation at constant $\mathrm{PCO}_{2} \cdot{ }^{6,9,10)}$ Our first and second experiments showed initial ICP reduction at the start of HBO inhalation in most spontaneously or artificially respirated patients. However, this study and others ${ }^{51}$ also showed that the ICP then increased gradually during HBO inhalation. Therefore, the vasoconstriction directly caused by HBO may only be temporary and diminishes with continued inhalation.

Our third experiment tested ICP responses to $\mathrm{PtcCO}_{2}$ during $\mathrm{HBO}$ inhalation. The ICP increased when the $\mathrm{PtcCO}_{2}$ returned to near the value at 2.5 ATA with air controlled by intentional respiration. This suggests that induced hypocapnia maintains the reduced ICP during $\mathrm{HBO}$ inhalation. The decreased arterial $\mathrm{PCO}_{2}$ during $\mathrm{HBO}$ inhalation is probably due to hyperventilation induced by transient $\mathrm{CO}_{2}$ 
retention. ${ }^{8,12)}$ This $\mathrm{CO}_{2}$ retention in the respiratory center may be due to diminished red blood cell transport capacity at considerably higher $\mathrm{O}_{2}$ pressure $^{11}$ and partly to diminished blood flow. ${ }^{31}$ The present study confirmed that the $\mathrm{PtcCO}_{2}$ decreased gradually following a transient increase and remained at a lower level throughout $\mathrm{HBO}$ inhalation. The changes in $\mathrm{ICP}$ reflecting changes in the $\mathrm{O}_{2}$ and $\mathrm{CO}_{2}$ pressures demonstrated by this study indicate that ICP reduction during HBO therapy is influenced by both hyperoxia and induced hypocapnia. The ICP is initially reduced by the direct vasoconstrictive effect of hyperoxia and is then maintained at a lower level mainly by induced hypocapnia during $\mathrm{HBO}$ inhalation.

HBO therapy is reported to promote recovery in patients with head injury or cerebral ischemia. ${ }^{7,11,13,20)}$ Clinically, four (Cases 7, 9-11) of our 11 patients showed neurological improvements. Animal experiments showed that $\mathrm{HBO}$ has protective effects in cerebral edema or ischemia, ${ }^{17-19)}$ and suppresses increased lactate levels in the ischemic brain. ${ }^{71}$ Contreras et $a l^{2 y}$ also showed that HBO inhalation increased cerebral glucose metabolism in a traumatized rat brain. This indicates that $\mathrm{HBO}$ therapy facilitates metabolic improvement in acute brain damage.

Reduced ICP was only demonstrated during $\mathrm{HBO}$ inhalation and the rebound phenomenon occurred after HBO therapy in the present study. Rapid vasodilation is considered to cause the rebound phenomenon since the direct vasoconstrictive effect of $\mathrm{HBO}$ becomes weak and there is a rapid return to lower arterial $\mathrm{PO}_{2}$ leve1s. ${ }^{5,11.15 .16)}$ Since the effect of $\mathrm{HBO}$ on ICP reduction is temporary, HBO therapy should be used when improvement in a hypoxic lesion is expected, rather than to reduce ICP. Moreover, in our study, low $\mathrm{PtcCO}_{2}$ could be achieved physiologically in spontaneously respirated patients. Normocapnia during HBO inhalation in artificially respirated patients will induce $\mathrm{CO}_{2}$ retention and result in increased arterial $\mathrm{PCO}_{2}$ and ICP. Therefore, HBO therapy requires care in patients with a high ICP and/or who are respirated artificially.

\section{Acknowledgment}

We thank Mr. H. Uemura and Mr. T. Ishikawa for their excellent technical assistance.

\section{References}

1) Christiansen J, Douglas CG, Haldane JS: The absorp- tion and dissociation of carbon dioxide by human blood. J Physiol (London) 48: 244-271, 1914

2) Contreras FL, Kadekaro M, Eisenberg HM: The effect of hyperbaric oxygen on glucose utilization in a freeze-traumatized rat brain. $J$ Neurosurg 68: 137141,1988

3) Dautrebande L, Haldane JS: The effects of respiration of oxygen on breathing and circulation. $J$ Physiol (London) 55: 296-299, 1921

4) Furset K, Aanderud L, Segadal K, Tyssebotn I: Transcutaneous measurement of $\mathrm{PCO}_{2}$ at high ambient pressure (41 bar). Undersea Biomed Res 15: 5162,1988

5) Hayakawa $T$, Kanai N, Kuroda R, Yamada $Y$, Mogami $\mathrm{H}$ : Response of cerebrospinal fluid pressure to hyperbaric oxygenation. I Neurol Neurosurg Psychiatry 34: 580-586, 1971

6) Jacobson I, Harper AM, McDowall DG: The effects of oxygen 1 and 2 atmospheres on the blood flow and oxygen uptake of the cerebral cortex. Surg Gynec Obstet 119: 737-742, 1964

7) Kapp JP: Neurological response to hyperbaric oxygen. A criterion for cerebral revascularization. Surg Neurol 15: 43-46, 1981

8) Lambertsen CJ, Kough RH, Cooper DY, Emmel GL, Loeschcke HH, Schmidt CF: Oxygen toxicity. Effects in man of oxygen inhalation at 1 and 3.5 atmospheres upon blood gas transport, cerebral circulation and cerebral metabolism. J Appl Physiol 5: 471486, 1953

9) Miller JD, Fitch W, Ledingham IM, Jennett WB: The effect of hyperbaric oxygen on experimentally increased intracranial pressure. J Neurosurg 33: 287296, 1970

10) Miller JD, Ledingham IM, Jennett WB: Effects of hyperbaric oxygen on intracranial pressure and cerebral blood flow in experimental cerebral edema. $J$ Neurol Neurosurg Psychiatry 33: 745-755, 1970

11) Mogami H, Hayakawa T, Kanai $N$, Kuroda R, Yamada R, Ikeda $Y$, Katsurada $K$, Sugimoto $T$ : Clinical application of hyperbaric oxygenation in the treatment of acute cerebral damage. $J$ Neurosurg 31 : 636-643, 1969

12) Nakajima $S$, Meyer JS, Amano $T$, Shaw $T$, Okabe T, Mortel KF: Cerebral vasomotor responsiveness during $100 \%$ oxygen inhalation in cerebral ischemia. Arch Neurol 40: 271-276, 1983

13) Neubauer RA, End E: Hyperbaric oxygenation as an adjunct therapy in strokes due to thrombosis. Stroke 11: $297-300,1980$

14) Ohta H: The effect of hyperoxemia on cerebral blood flow in normal humans. No To Shinkei 38: 949-959, 1986 (in Japanese)

15) Ohta $H$, Hadeishi $H$, Nemoto $N$, Kawamura $S$, Hinuma Y, Suzuki E: Transient effect of hyperbaric oxygen on cerebral blood flow and intracranial pressure. Journal of Hyperbaric Medicine 5: 3-13, 1990

16) Ohta H, Kawamura S, Nemoto M, Kitami K, Yasui 
N, Hinuma Y, Suzuki E: Treatment of increased intracranial pressure by hyperbaric oxygenation. Neurol Med Chir (Tokyo) 26: 385-391, 1986 (in Japanese)

17) Shiokawa O, Fujishima M, Yanai T, Ibayashi $S$, Ueda $K$, Yagi $H$ : Hyperbaric oxygen therapy in experimentally induced acute cerebral ischemia. Undersea Biomed Res 13: 337-344, 1986

18) Sukoff $\mathbf{M H}$, Hollin SA, Espinosa OE, Jacobson $\mathbf{J H}$; The protective effect of hyperbaric oxygenation in experimental cerebral edema. I Neurosurg 29: 236-241, 1968

19) Sukoff $\mathrm{MH}$, Hollin SA, Jacobson JH: The protective effect of hyperbaric oxygenation in experimentally produced cerebral edema and compression. Surgery
62: $40-46,1967$

20) Sukoff $M H$, Ragatz RE: Hyperbaric oxygenation for the treatment of acute cerebral edema. Neurosurgery 10: 29-38, 1982

21) Tindall GT, Wilkins RH, Odom GL: Effect of hyperbaric oxygenation on cerebral blood flow. Surg Forum 16: 414-416, 1965

Address reprint requests to: K. Kohshi, M.D., Departments of Hyperbaric Medicine and Neurosurgery, University of Occupational and Environmental Health, 1-1 Iseigaoka, Yahata-nishi-ku, Kitakyushu, Fukuoka 807, Japan. 